\title{
Neutralization of Soybean Oil Deodorizer Distillate for Vitamin Supplement Production
}

\author{
Cibelem Iribarrem Benites, ${ }^{1,2}$ Bruno Colling Klein, ${ }^{1}$ and Soely Maria Pissini Machado Reis ${ }^{2}$ \\ ${ }^{1}$ School of Chemical Engineering (FEQ), University of Campinas (UNICAMP), 13083-852 Campinas, SP, Brazil \\ ${ }^{2}$ School of Food Engineering (FEA), University of Campinas (UNICAMP), 13083-862 Campinas, SP, Brazil \\ Correspondence should be addressed to Cibelem Iribarrem Benites; bele_benites@yahoo.com.br
}

Received 25 November 2013; Revised 1 March 2014; Accepted 3 March 2014; Published 1 April 2014

Academic Editor: Deepak Kunzru

Copyright (c) 2014 Cibelem Iribarrem Benites et al. This is an open access article distributed under the Creative Commons Attribution License, which permits unrestricted use, distribution, and reproduction in any medium, provided the original work is properly cited.

\begin{abstract}
Soybean oil deodorizer distillate (SODD), a byproduct of the soybean oil refining process, is a complex mixture of compounds, such as free fatty acids (FFA), hydrocarbons, and sterols, such as tocopherols, a class of major natural antioxidants with vitamin $\mathrm{E}$ activity. As the utilization of SODD for tocopherol extraction is shown to be not economically viable, SODD in the semirefined form (neutral) is an interesting alternative to animal and possibly human diet enrichment. This study aimed to evaluate the SODD neutralization process varying the alkali $\left(\mathrm{Na}_{2} \mathrm{CO}_{3}\right)$ concentration, temperature, and homogenization time. The optimal conditions for the neutralizing process, in order to obtain the greatest reduction in FFA content, the lowest leaching of tocopherols, and the greatest yield, were the following: $\mathrm{Na}_{2} \mathrm{CO}_{2}$ concentration of $4.34 \mathrm{~N}$, temperature of $45.8^{\circ} \mathrm{C}$, and homogenization time of $3 \mathrm{~min} 20 \mathrm{~s}$. The FFA content was reduced from $53.4 \%$ to $6.1 \%$ after the initial neutralization, thus requiring a second neutralization step. The final FFA content was of $1.8 \%$ and total tocopherol (TT) accounted for about $11 \%$ of SODD.
\end{abstract}

\section{Introduction}

The global edible oils manufacturing industry processes a great amount of raw vegetable oils, which must undergo refining in order to become suitable for human consumption. The soybean oil deodorizer distillate (SODD) is obtained during the deodorization step, designed to remove compounds that confer odor and flavor to the oil and are volatile [1]. The objectives of current deodorization processes are stripping of volatile components, valuable minor components, and contaminants; removal of flavors; and thermal destruction of pigments [2]. This process is carried out by steam distillation, which prevents both oil oxidation (by avoiding contact with atmospheric oxygen) and oil hydrolysis [3]. In general, the distillation column operates with temperatures between 200 and $250^{\circ} \mathrm{C} \mathrm{[4]} \mathrm{and} \mathrm{under} \mathrm{vacuum} \mathrm{as} \mathrm{low} \mathrm{as} 10 \mathrm{mmHg}$, thus yielding two streams: a bottom stream, which comprises the refined oil, and a top stream containing the deodorizer distillate [5]. Throughout the deodorization process, besides volatile products from oxidation reactions, a fraction of lipids, tocopherols, and phytosterols present in the oil is also entrained.

Augusto [6] notes that the SODD is a heterogeneous, complex mixture, rich in free fatty acids (FFA), specially palmitic and linoleic acids, total sterols (20\%), $\beta$-sitosterol (9\%), and total tocopherols (10\%). Besides, other compounds are present in the mixture, such as partial acylglycerols, triacylglycerols, peroxides, high-molecular-weight unsaturated aldehydes, ketones, paraffinic hydrocarbons, oleins, squalene, and nonidentified oxidized products.

As the SODD is a very abundant byproduct of the vegetable oil industry, it can be further processed to obtain a series of consumer products. Since tocopherols are a class of compounds with vitamin E activity, they can be concentrated in the SODD in order to produce a viable vitamin supplement, as an alternative to synthetic vitamins [7]. According to the literature, one of the main methods to achieve this class of products is through the neutralization of the FFA present in SODD via alkali addition. In the raw 
SODD neutralization step, the main process variables are temperature, alkali concentration, and its contact time with the product. Neutralization conditions are chosen based on both the short mix process, usually performed in industrial rice oil refining with high alkali concentration, high temperature, and low homogenization time and on the researcher's experience. According to Benites [8], $\mathrm{Na}_{2} \mathrm{CO}_{3}$ presents the best results in such type of neutralization, thus being used as the neutralizing agent in this study.

In short, the utilization of SODD as a nutritional product follows the global tendency of using natural ingredients as a potential industrial feedstock. Thus, the goal of this study is to implement a neutralization step of raw SODD, aiming at the reduction of FFA content and a greater yield of $\alpha$-tocopherol, so as to evaluate the feasibility of its utilization as a natural vitamin E supplement.

\section{Materials and Methods}

2.1. SODD Neutralization. Raw SODD (kindly provided by Cargill Agrícola S.A., Brazil), stored at $-10^{\circ} \mathrm{C}$, was liquefied in a water bath at $25^{\circ} \mathrm{C}$. Studies on SODD neutralization were conducted by investigating different variable levels (alkali concentration, temperature, and reaction time) in two sequential experimental designs, as detailed in Section 2.3.

A sample was weighed in a beaker and immersed in a water bath at the chosen experiment temperature. $\mathrm{Na}_{2} \mathrm{CO}_{3}$ in stoichiometric excess was slowly added to the SODD and the mixture was vigorously agitated for the specific experiment time. Afterwards, the beaker was transferred to a water bath at $40^{\circ} \mathrm{C}$ for $3 \mathrm{~h}$ in order to achieve phase separation. To increase separation efficiency, the mixture was centrifuged at $5858 \times \mathrm{g}$ for $15 \mathrm{~min}$ (Sorvall RC-5C, Thermo Scientific, USA). The mixture was further washed with hot water at a 1:1 ratio and recentrifuged at the same conditions. After sludge separation, neutral SODD was obtained.

2.2. Analytical Methods. FFA determination was carried out according to method 940.28 of the AOAC [9] and tocopherol content was measured through high pressure liquid chromatography (HPLC-method Ce 8-89 of the AOCS) [10]. Tocopherol isomers were identified through comparison of retention times, cochromatography, and absorption spectra of the sample with $\alpha-, \beta-, \gamma^{-}$, and $\delta$-tocopherols (95\% purity, Calbiochem, USA). Tocopherol quantification was carried out with an external standard. The HPLC system consists of the following equipment: isocratic pump (model 250, Perkin Elmer, USA); fluorescence detector (RF-10 AXL, Shimadzu, Japan); analytical column coupled with guard column (250 $\times 4 \mathrm{~mm}$ LiChrosorb Si 60, Merck, USA). The mobile phase was a 99:1 mixture of HPLC-grade hexane and isopropanol (filtered and degassed with ultrasound for $10 \mathrm{~min}$ ), injected at a $1.1 \mathrm{~mL} / \mathrm{min}$ flow rate. The detector used excitation and emission wavelengths of 290 and $330 \mathrm{~nm}$, respectively.

2.3. Experimental Design. The first experimental design is a type $2^{3}$ full factorial design, with four replicates of the central point. The second one is a central composite experimental design, with both axial and central points, which allows the obtention of a quadratic model in order to better represent the optimal SODD neutralization region. The conditions employed in both first and second experimental designs are shown in Table 1 . The results from each experimental design were statistically analyzed using the Statistica software (StatSoft v.7.0). The effect of each variable was evaluated in order to obtain the best conditions for SODD neutralization.

\section{Results and Discussion}

3.1. First Experimental Design. The coded and real values of the variables used in the first neutralization experimental design and the main desired responses, namely, reduction of FFA content, total $\alpha$-tocopherol equivalents ( $\alpha$-TE) content, and neutral SODD yield, are shown in Table 2. Since the most important parameter for vitamin supplementation production is total $\alpha$-tocopherol content and each tocopherol isomer has a different vitamin E activity, the following conversion factors for $\alpha$-TE determination are used: $\beta$-tocopherol 0.4027; $\gamma$-tocopherol 0.1275; and $\delta$-tocopherol 0.0067 [11].

The greatest reductions in FFA content were obtained in the assays in which $\mathrm{Na}_{2} \mathrm{CO}_{3}$ concentration and reaction temperature were closer to the maximum studied levels. The same behavior was observed for $\alpha$-TE content, where higher levels were achieved with high temperature and high $\mathrm{Na}_{2} \mathrm{CO}_{3}$ concentration. In relation to neutral SODD yield, the highest levels were obtained with lower temperatures and higher $\mathrm{Na}_{2} \mathrm{CO}_{3}$ concentrations, independent of the reaction time. This result contrasts with the two previous ones; that is, while a high temperature level boosts the neutral SODD yield, it hinders the obtention of high $\alpha$-TE and low FFA contents. Among the three analyzed responses, $\alpha$-TE content in SODD is the most important one, since the neutralization reaction with the least tocopherol drag to the sludge is the most economically interesting process.

3.2. Second Experimental Design. As responses were not optimized in the first experimental design, the variables' levels were altered in the second one, aiming to obtain a quadratic model to better describe the neutralization process and to get closer to the optimal point. Table 3 shows the real and coded values of the variables and the results for the main studied responses.

3.2.1. Response: Reduction of FFA Content. The best results for the reduction of FFA content in neutralized SODD were achieved with lower $\mathrm{Na}_{2} \mathrm{CO}_{3}$ concentrations, from the lowest studied level $(3 \mathrm{~N})$ to the central level $(3.5 \mathrm{~N})$. Since all the results for this response were in the range of 49.3 to $50.8 \%$, the statistical variation was not considered to be significant from a chemical point of view.

Based on the analysis, the reduction of FFA content can be evaluated from the following model based on coded variables: 
TABLE 1: Levels and ranges of the independent variables $\left(\mathrm{Na}_{2} \mathrm{CO}_{3}\right.$ concentration, temperature, and time) employed in the first and second experimental designs.

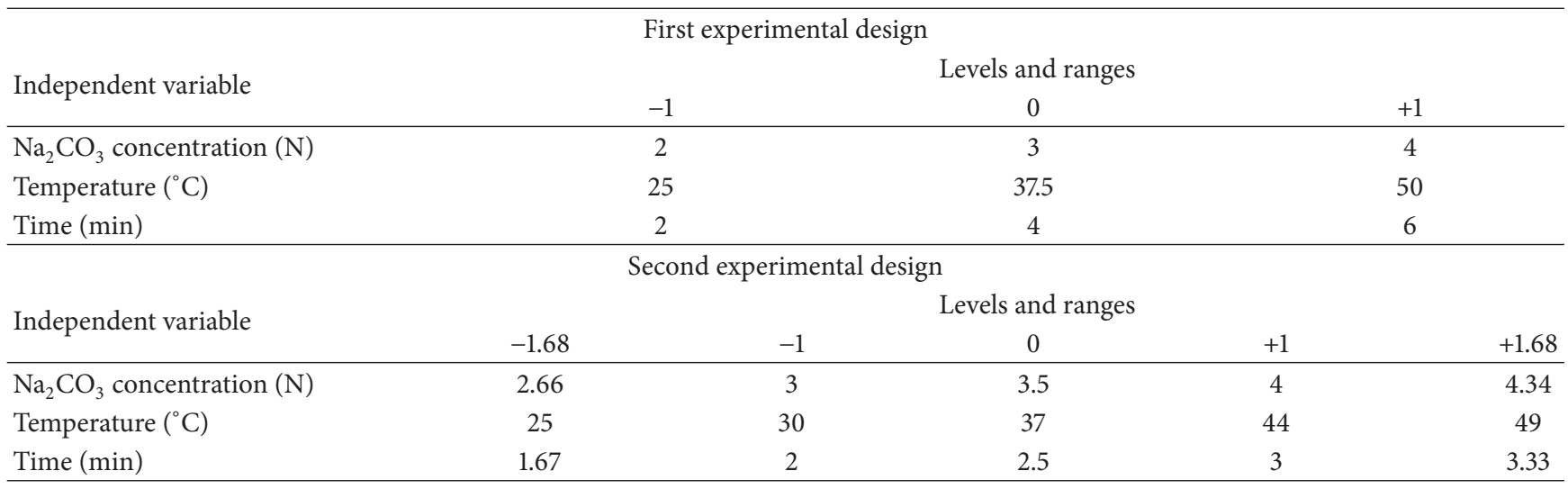

TABLE 2: First experimental design matrix with real and coded variables' values and studied responses.

\begin{tabular}{|c|c|c|c|c|c|c|}
\hline \multirow{2}{*}{ Assay } & \multicolumn{3}{|c|}{ Factors } & \multicolumn{3}{|c|}{ Responses } \\
\hline & $\begin{array}{c}\mathrm{Na}_{2} \mathrm{CO}_{3} \text { concentration } \\
(\mathrm{N})\end{array}$ & $\begin{array}{c}\text { Temperature } \\
\left({ }^{\circ} \mathrm{C}\right)\end{array}$ & $\begin{array}{l}\text { Time } \\
(\mathrm{min})\end{array}$ & $\begin{array}{l}\text { Reduction of FFA } \\
\text { content }(\%)\end{array}$ & $\begin{array}{c}\alpha \text {-TE content } \\
(\%)\end{array}$ & $\begin{array}{c}\text { Neutral SODD yield } \\
(\%)\end{array}$ \\
\hline 1 & $2(-1)$ & $25(-1)$ & $2(-1)$ & $32.6^{\mathrm{a}}$ & $1.724^{\mathrm{a}}$ & $33.0^{\mathrm{c}}$ \\
\hline 2 & $4(1)$ & $25(-1)$ & $2(-1)$ & $34.3^{\mathrm{c}}$ & $1.797^{\mathrm{a}}$ & $42.5^{\mathrm{d}}$ \\
\hline 3 & $2(-1)$ & $50(1)$ & $2(-1)$ & $40.1^{\mathrm{de}}$ & $2.346^{\mathrm{bc}}$ & $7.5^{\mathrm{a}}$ \\
\hline 4 & $4(1)$ & $50(1)$ & $2(-1)$ & $41.6^{\mathrm{f}}$ & $2.750^{\mathrm{d}}$ & $14.7^{\mathrm{b}}$ \\
\hline 5 & $2(-1)$ & $25(-1)$ & $6(1)$ & $32.5^{\mathrm{a}}$ & $1.685^{\mathrm{a}}$ & $36.9^{\mathrm{cd}}$ \\
\hline 6 & $4(1)$ & $25(-1)$ & $6(1)$ & $33.4^{\mathrm{b}}$ & $1.691^{\mathrm{a}}$ & $42.2^{\mathrm{d}}$ \\
\hline 7 & $2(-1)$ & $50(1)$ & $6(1)$ & $39.8^{\mathrm{de}}$ & $2.416^{\mathrm{c}}$ & $12.9^{\mathrm{ab}}$ \\
\hline 8 & $4(1)$ & $50(1)$ & $6(1)$ & $42.6^{\mathrm{g}}$ & $2.585^{\mathrm{cd}}$ & $12.8^{\mathrm{ab}}$ \\
\hline $\mathrm{CP}$ & $3(0)$ & $37.5(0)$ & $4(0)$ & $40.6^{\mathrm{e}}$ & $2.710^{\mathrm{d}}$ & $16.9^{\mathrm{b}}$ \\
\hline
\end{tabular}

Distinct letters in the same column indicate significant difference $(P<0.05)$ between values according to Tukey's test. CP: central point $(m e a n$ value of the quadruplicate).

TABLE 3: Second experimental design matrix with real and coded variables' values and studied responses.

\begin{tabular}{|c|c|c|c|c|c|c|}
\hline \multirow{2}{*}{ Assay } & \multicolumn{3}{|c|}{ Factors } & \multicolumn{3}{|c|}{ Responses } \\
\hline & $\begin{array}{c}\mathrm{Na}_{2} \mathrm{CO}_{3} \text { concentration } \\
(\mathrm{N})\end{array}$ & $\begin{array}{c}\text { Temperature } \\
\left({ }^{\circ} \mathrm{C}\right)\end{array}$ & $\begin{array}{l}\text { Time } \\
(\min )\end{array}$ & $\begin{array}{l}\text { Reduction of FFA } \\
\text { content }(\%)\end{array}$ & $\begin{array}{c}\alpha \text {-TE content } \\
(\%)\end{array}$ & $\begin{array}{c}\text { Neutral SODD yield } \\
(\%)\end{array}$ \\
\hline 1 & $3(-1)$ & $30(-1)$ & $2(-1)$ & $49.3^{\mathrm{a}}$ & $2.489^{\mathrm{a}}$ & $5.2^{\mathrm{a}}$ \\
\hline 2 & $4(1)$ & $30(-1)$ & $2(-1)$ & $50.5^{\mathrm{bcd}}$ & $2.738^{\mathrm{a}}$ & $13.4^{\text {cde }}$ \\
\hline 3 & $3(-1)$ & $44(1)$ & $2(-1)$ & $49.3^{\mathrm{a}}$ & $2.151^{\mathrm{a}}$ & $7.7^{\mathrm{ab}}$ \\
\hline 4 & $4(1)$ & $44(1)$ & $2(-1)$ & $50.2^{\mathrm{bc}}$ & $2.365^{\mathrm{a}}$ & $13.0^{\text {cde }}$ \\
\hline 5 & $3(-1)$ & $30(-1)$ & $3(1)$ & $49.5^{\mathrm{a}}$ & $2.214^{\mathrm{a}}$ & $5.5^{\mathrm{a}}$ \\
\hline 6 & $4(1)$ & $30(-1)$ & $3(1)$ & $50.1^{\mathrm{b}}$ & $2.515^{\mathrm{a}}$ & $14.9^{\mathrm{e}}$ \\
\hline 7 & $3(-1)$ & $44(1)$ & $3(1)$ & $49.7^{\mathrm{ab}}$ & $2.304^{\mathrm{a}}$ & $10.6^{\text {bcde }}$ \\
\hline 8 & $4(1)$ & $44(1)$ & $3(1)$ & $50.8^{\mathrm{d}}$ & $2.737^{\mathrm{a}}$ & $14.3^{\mathrm{de}}$ \\
\hline 9 & $2.66(-1.68)$ & $37(0)$ & $2.5(0)$ & $49.6^{\mathrm{a}}$ & $2.285^{\mathrm{a}}$ & $7.0^{\mathrm{a}}$ \\
\hline 10 & $4.34(1.68)$ & $37(0)$ & $2.5(0)$ & $50.8^{\mathrm{d}}$ & $2.681^{\mathrm{a}}$ & $24.5^{\mathrm{f}}$ \\
\hline 11 & $3.5(0)$ & $25(-1.68)$ & $2.5(0)$ & $49.6^{\mathrm{a}}$ & $2.576^{\mathrm{a}}$ & $11.6^{\text {bcde }}$ \\
\hline 12 & $3.5(0)$ & 49 (1.68) & $2.5(0)$ & $49.6^{\mathrm{a}}$ & $2.342^{\mathrm{a}}$ & $10.4^{\mathrm{bcd}}$ \\
\hline 13 & $3.5(0)$ & $37(0)$ & $1.67(-1.68)$ & $49.6^{\mathrm{a}}$ & $2.304^{\mathrm{a}}$ & $9.2^{\mathrm{abc}}$ \\
\hline 14 & $3.5(0)$ & $37(0)$ & $3.33(1.68)$ & $50.2^{\mathrm{bc}}$ & $2.367^{\mathrm{a}}$ & $13.3^{\text {cde }}$ \\
\hline $\mathrm{CP}$ & $3.5(0)$ & $37(0)$ & $2.5(0)$ & $50.2^{\mathrm{bc}}$ & $2.304^{\mathrm{a}}$ & $12.9^{\text {cde }}$ \\
\hline
\end{tabular}

Distinct letters in the same column indicate significant difference $(P<0.05)$ between values according to Tukey's test. CP: central point (mean value of the quadruplicate). 
TABLE 4: Tocopherol content in raw and neutralized SODD obtained in the second experimental design.

\begin{tabular}{|c|c|c|c|c|c|}
\hline SODD & $\alpha$-Tocopherol (\%) & $\beta$-Tocopherol (\%) & $\gamma$-Tocopherol (\%) & $\delta$-Tocopherol (\%) & Total tocopherol (\%) \\
\hline Raw SODD & 1.28 & 0.22 & 6.59 & 2.36 & 10.44 \\
\hline \multicolumn{6}{|l|}{ Neutral } \\
\hline 1 & 1.67 & 0.22 & 5.67 & 1.60 & 9.15 \\
\hline 2 & 1.82 & 0.25 & 6.32 & 1.77 & 10.16 \\
\hline 3 & 1.46 & 0.21 & 4.69 & 1.39 & 7.75 \\
\hline 4 & 1.60 & 0.22 & 5.27 & 1.53 & 8.61 \\
\hline 5 & 1.51 & 0.20 & 4.82 & 1.44 & 7.97 \\
\hline 6 & 1.69 & 0.22 & 5.69 & 1.64 & 9.24 \\
\hline 7 & 1.56 & 0.22 & 5.09 & 1.50 & 8.36 \\
\hline 8 & 1.82 & 0.25 & 6.29 & 1.77 & 10.14 \\
\hline 9 & 1.55 & 0.21 & 5.03 & 1.47 & 8.25 \\
\hline 10 & 1.80 & 0.24 & 6.09 & 1.75 & 9.88 \\
\hline 11 & 1.74 & 0.23 & 5.79 & 1.61 & 9.36 \\
\hline 12 & 1.59 & 0.21 & 5.13 & 1.49 & 8.43 \\
\hline 13 & 1.56 & 0.21 & 5.07 & 1.48 & 8.32 \\
\hline 14 & 1.60 & 0.22 & 5.26 & 1.56 & 8.64 \\
\hline CP & 1.56 & 0.21 & 5.08 & 1.50 & 8.35 \\
\hline
\end{tabular}

CP: central point (mean value of the quadruplicate).

TABLE 5: ANOVA of the responses in the second experimental design.

\begin{tabular}{|c|c|c|c|c|c|}
\hline Source of variation & Sum of squares & Degrees of freedom & Mean square & $F_{\text {calculated }}$ & $F_{\text {tabulated }}$ \\
\hline \multicolumn{6}{|c|}{ Response: reduction of FFA content } \\
\hline Regression & 6.404 & 7 & 0.915 & 32.8265 & 2.4422 \\
\hline Residues & 0.641 & 23 & 0.028 & & \\
\hline Lack of fit & 0.433 & 7 & 0.062 & & \\
\hline Pure error & 0.208 & 16 & 0.013 & & \\
\hline Total & 7.045 & 30 & & & \\
\hline \multicolumn{6}{|c|}{ Response: $\alpha$-TE content } \\
\hline Regression & 0.960 & 7 & 0.137 & 5.2655 & 2.4422 \\
\hline Residues & 0.599 & 23 & 0.026 & & \\
\hline Lack of fit & 0.039 & 7 & 0.006 & & \\
\hline Pure error & 0.561 & 16 & 0.035 & & \\
\hline Total & 1.560 & 30 & & & \\
\hline \multicolumn{6}{|c|}{ Response: neutral SODD yield } \\
\hline Regression & 373.734 & 7 & 53.391 & 4.2962 & 2.4422 \\
\hline Residues & 285.831 & 23 & 12.427 & & \\
\hline Lack of fit & 65.269 & 7 & 9.324 & & \\
\hline Pure error & 220.562 & 16 & 13.785 & & \\
\hline Total & 659.565 & 30 & & & \\
\hline
\end{tabular}

Reduction of FFA (\%)

$$
\begin{aligned}
= & 50.15+0.42 C+0.03 T+0.12 t \\
& +0.01 C^{2}-0.19 T^{2}-0.09 t^{2}+0.14 T t
\end{aligned}
$$

where $C, T$, and $t$ are alkali concentration, temperature, and time, respectively. The interactions between factors without statistical significance $(P>0.05)$ were removed from the mathematical model.
Table 5 presents the analysis of variance (ANOVA) for this response. The ratio between $F_{\text {calculated }}(32.83)$ and $F_{\text {tabulated }}$ $\left(F_{0.95 ; 7 ; 23}=2.44\right)$ is 13.46 , which confirms the adequacy of the quadratic model. The explained variance $\left(R^{2}\right)$ is $90.9 \%$ and the maximum explainable variance corresponds to $97.1 \%$.

The highest reductions of FFA content occur with higher $\mathrm{Na}_{2} \mathrm{CO}_{3}$ concentrations, intermediate temperature levels, and intermediate reaction time. The response surface presented in Figure 1 shows the interaction between factors with statistical significance, temperature, and time of reaction. 


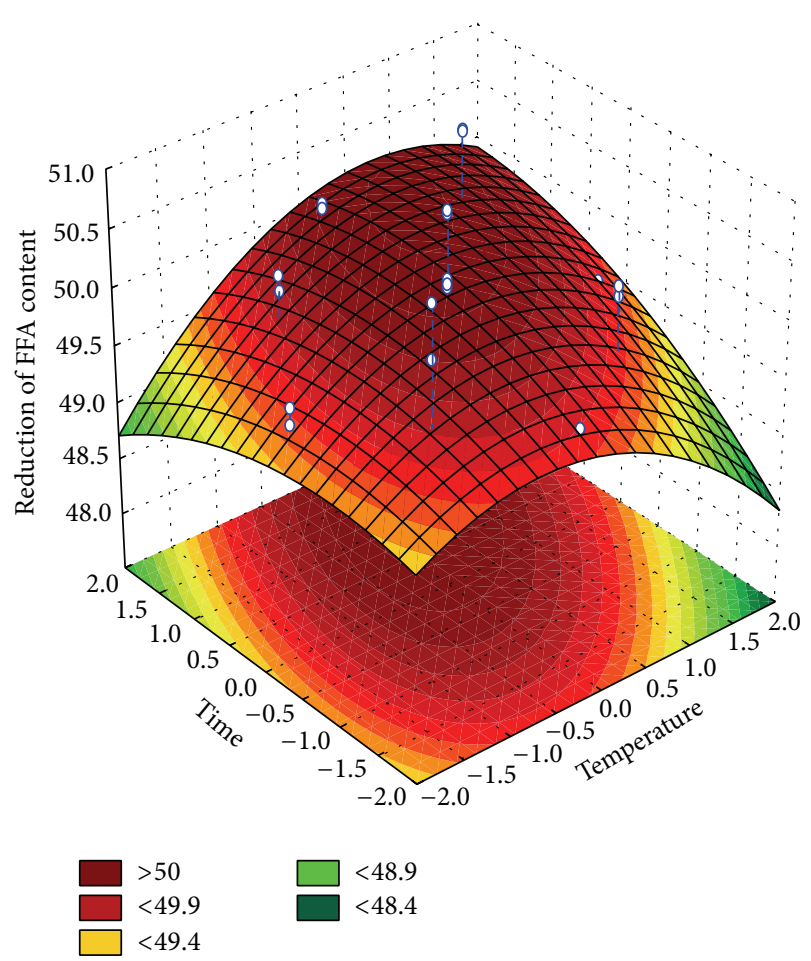

FIGURE 1: Response surface for the reduction of FFA content in the second experimental design, effects of temperature, and time of reaction (coded values at axis).

3.2.2. Response: $\alpha$-TE Content. Table 4 presents the content of each tocopherol isomer, as well as total tocopherols, in both raw and neutralized SODD obtained via the second experimental design. $\alpha$-TE content in neutral SODD did not significantly vary among the assays $(P>0.05)$.

In the construction of the mathematical model, the nonsignificant interactions between factors were ignored; using the same convention for the variables as in Section 3.2.1 is adopted:

$$
\begin{aligned}
\alpha-\text { TE content }(\%)= & 2.30+0.14 C-0.06 T+0.01 t \\
& +0.06 C^{2}-0.06 T^{2}+0.01 t^{2}+0.13 T t
\end{aligned}
$$

The ANOVA (Table 5) for this response shows that the explained variance is of $61.6 \%$ and the maximum explainable variance corresponds to $64.1 \%$. The $F$-test yields a ratio of 2.16 $\left(F_{\text {calculated }}=5.27\right.$ and $\left.F_{0.95 ; 7 ; 23}=2.44\right)$, indicating that the quadratic model is not the best option for describing $\alpha$-TE content in this experimental design.

3.2.3. Response: Neutral SODD Yield. The obtained results show that neutral SODD yield is greater with higher or intermediate $\mathrm{Na}_{2} \mathrm{CO}_{3}$ concentrations, which coincide with the behavior of the two previously analyzed responses. For

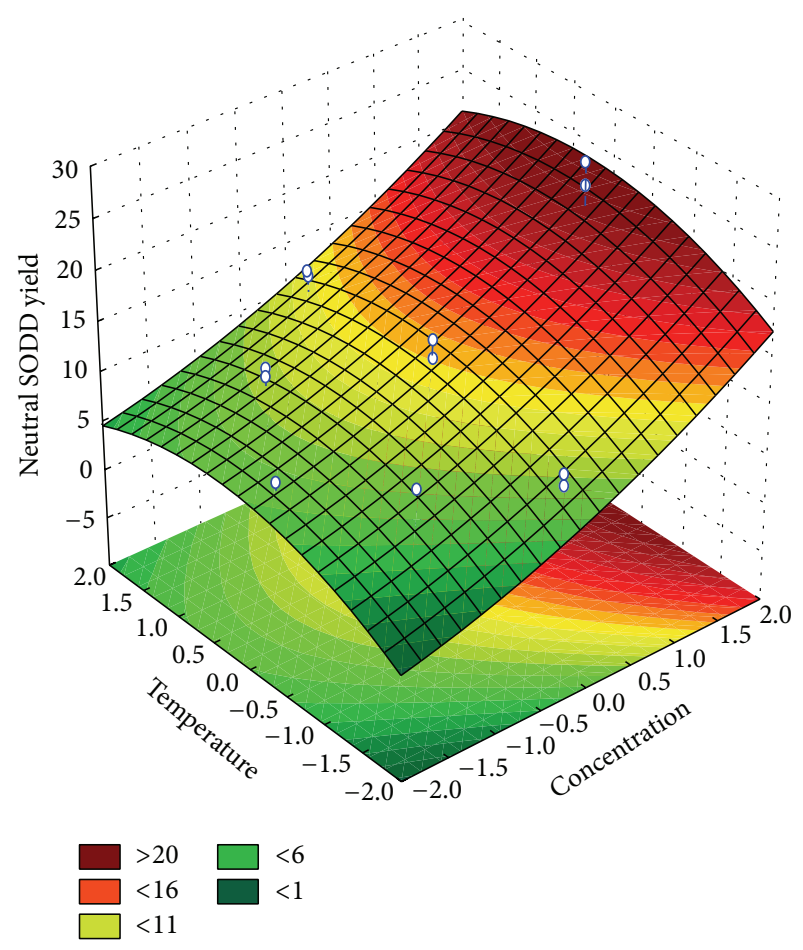

FIGURE 2: Response surface for neutral SODD yield in the second experimental design, effect of $\mathrm{Na}_{2} \mathrm{CO}_{3}$ concentration, and temperature (coded values at axis).

the construction of the mathematical model, nonsignificant interactions between factors were ignored:

$$
\begin{aligned}
& \text { Neutral SODD yield }(\%) \\
& \begin{aligned}
= & 13.18+4.11 C+0.33 T+0.95 t \\
& +0.51 C^{2}-1.18 T^{2}-1.09 t^{2}+1.08 C T,
\end{aligned}
\end{aligned}
$$

where the same convention for the variables as in Section 3.2.1 is adopted.

According to Table 5, the $F$-test results in a ratio of 1.76 $\left(F_{\text {calculated }}=4.30\right.$ and $\left.F_{0.95 ; 7 ; 23}=2.44\right)$, which denotes that the model does not fit the experimental data satisfactorily. The explained variance is $56.7 \%$ and the maximum explainable variance corresponds to $66.6 \%$.

The behavior of neutral SODD yield and reduction of FFA content are similar: the highest values are found with higher $\mathrm{Na}_{2} \mathrm{CO}_{3}$ concentrations and intermediate levels of reaction temperature and time, with a well-defined optimal region. The response surface presented in Figure 2 shows the factors' interaction with statistical significance.

As a whole, it was verified with this experimental design that all responses were favored at higher $\mathrm{Na}_{2} \mathrm{CO}_{3}$ concentrations, although the optimal region for $\alpha$-TE content was not totally clarified.

3.2.4. Desirability Analysis. With the Statistica software (StatSoft v.7.0), a desirability analysis was conducted, in which a relation between the predicted values of the dependent 

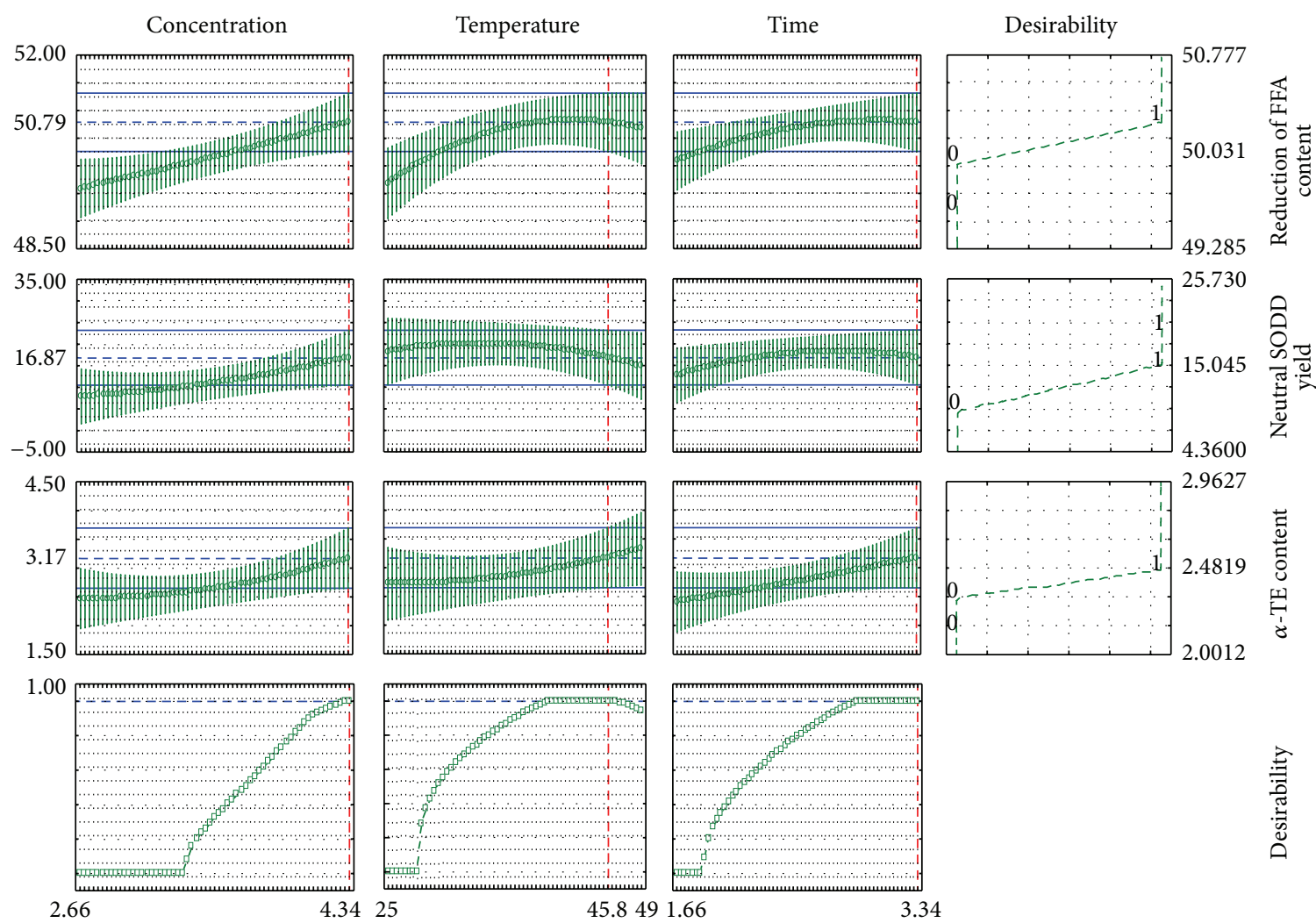

FIGURE 3: Predicted values and desirability analysis of the dependent variables in the second experimental design.

variables (reduction of FFA content, $\alpha$-TE content, and neutral SODD yield) and the values desired by the researcher is established. The analysis involves the attribution of coefficients to each dependent variable, which varies from 0 (very undesirable) to 1 (very desirable). The individual counts are combined and the geometric mean is calculated. The desirability profiles consist in a series of graphics, one for each dependent variable. These profiles can show in which variable levels the most desired responses may be obtained. The coefficient of the most relevant dependent variables (reduction of FFA content and $\alpha$-TE content) was set as 1 at their maxima. For neutral SODD yield, this coefficient was set for both maximum and intermediate values, indicating that either result is satisfactory.

The analysis of the graphics shown in Figure 3 denotes that the best SODD neutralization conditions are $\mathrm{Na}_{2} \mathrm{CO}_{3}$ concentration of $4.34 \mathrm{~N}$, temperature of $45.8^{\circ} \mathrm{C}$, and homogenization time of $3.33 \mathrm{~min}$. These values provide less acidity, less tocopherol drag to the sludge, and higher quantities of neutral SODD.

The neutralization process is necessary to allow the use of SODD, since FFA are harmful to cells and the tocopherols are difficult to extract [11]. Therefore the process proposed in this paper is promising because it removes the FFA, without loss of content of tocopherols, supplying a product with characteristics suitable for consumption.

In possession of the optimal conditions of the second experimental design, a neutralization was carried out and the neutral SODD was analyzed, as shown by Benites [12].
FFA content varied from $53.8 \%$ in raw SODD to $1.8 \%$ in neutral SODD, which corresponds to a reduction of $96.7 \%$. Also, total tocopherol content remained nearly constant, of $10.44 \%$ and $10.98 \%$ for raw and neutral SODD, respectively. Thus, it can be said that neutralization with $\mathrm{Na}_{2} \mathrm{CO}_{3}$ can effectively remove FFA without the loss of tocopherols. As a whole, the process leads to a reduction in the total mass of obtained neutral SODD due to the removal of FFA through saponification reactions.

\section{Conclusion}

In the conditions evaluated in this study, the implementation of the SODD neutralization process was advantageous. Moreover, the stage of FFA content removal can facilitate the concentration or purification of tocopherols.

With the purpose of studying the viability of an industrial byproduct as a natural source of tocopherols (vitamin E), neutral SODD presented a great utilization potential, with low cost and simple obtention method. There is high possibility of this product being used as animal feed without presenting the adverse effects caused by FFA excess. The intake of neutral SODD by animals may be beneficial to their health as well as improve meat quality for human consumption.

\section{Conflict of Interests}

The authors declare that there is no conflict of interests regarding the publication of this paper. 


\section{Acknowledgments}

The authors are grateful to Dr. Admar Costa de Oliveira (In memoriam), the São Paulo Research Foundation (FAPESP Proc. no. 2009/09836-9), and the National Council for Scientific and Technological Development $(\mathrm{CNPq})$ for the financial support.

\section{References}

[1] R. Verhé, T. Verleyen, V. van Hoed, and W. de Greyt, "Influence of refining of vegetable oils on minor components," Journal of Oil Palm Research, pp. 168-179, 2006.

[2] W. F. J. de Greyt, "Current and future technologies for the sustainable and cost-efficient production of high quality food oils," European Journal of Lipid Science and Technology, vol. 114, pp. 1126-1139, 2012.

[3] W. De Greyt and M. Kellens, "Refining practice," in Edible Oil Processing, W. Hamm and R. J. Hamilton, Eds., Blackwell, Danvers, Mass, USA, 2000.

[4] J. Pokorný and J. Korczak, "Preparation of natural antioxidants," in Antioxidants in Foods-Practical Applications, J. Pokorný, N. Yanishlieva, and M. Gordon, Eds., chapter 13, Woodhead Publishing, Cambridge, UK, 2001.

[5] T. Verleyen, R. Verhe, L. Garcia, K. Dewettinck, A. Huyghebaert, and W. De Greyt, "Gas chromatographic characterization of vegetable oil deodorization distillate," Journal of Chromatography A, vol. 921, no. 2, pp. 277-285, 2001.

[6] M. M. M. Augusto, Obtenção e caracterização de um concentrado de tocoferóis (vitamina E) a partir do destilado da desodorização do óleo de soja [M.S. thesis], University of Campinas, Campinas, Brazil, 1988.

[7] P. F. Martins, C. B. Batistella, R. Maciel-Filho, and M. R. WolfMaciel, "Comparison of two different strategies for tocopherols enrichment using a molecular distillation process," Industrial and Engineering Chemistry Research, vol. 45, no. 2, pp. 753-758, 2006.

[8] C. I. Benites, S. M. P. M. Reis, and A. C. Oliveira, "Avaliação de métodos de neutralização do destilado da desodorização do óleo de soja (DDOS)," in II Simpósio Internacional Tendências e Inovações em Tecnologia de Óleos e Gorduras, pp. 25-28, Sociedade Brasileira de Óleos e Gorduras, Florianópolis/SC, Brazil, 2005.

[9] P. Cunniff, A.O.A.C. Official Methods of Analysis of AOAC International, vol. 1, AOAC International, Arlington, Va, USA, 16th edition, 1995.

[10] A.O.C.S. Official Methods and Recommended Practices of the American Oil Chemist's Society, AOCS, Champaign, Ill, USA, 5th edition, 1998.

[11] H. K. Biesalski and P. Grimm, Nutrição-texto e atlas, Artmed, Porto Alegre, Brasil, 2007.

[12] C. I. Benites, V. O. C. Cardenas, S. M. P. M. Reis, and A. C. Oliveira, "Physiochemical characterization of soybean oil deodorizer distillate," Chemical Engineering Transactions, vol. 17, pp. 903-908, 2009. 

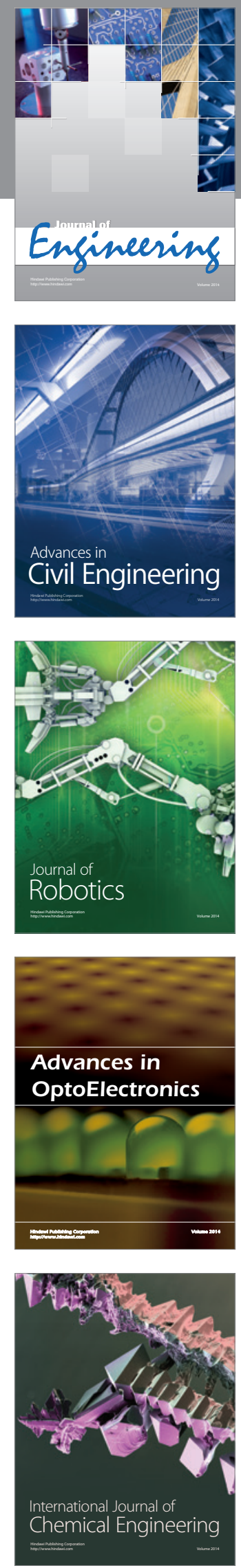

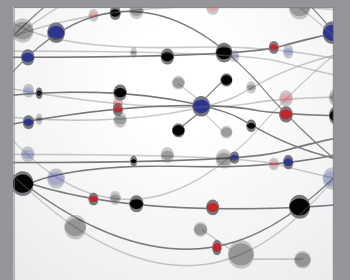

The Scientific World Journal
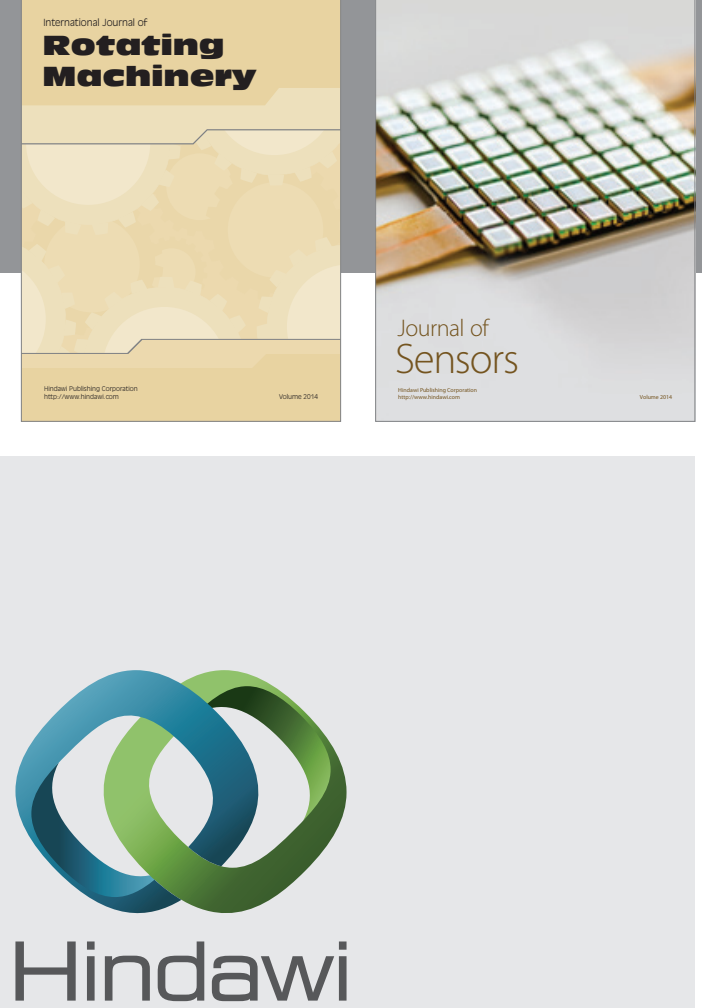

Submit your manuscripts at http://www.hindawi.com
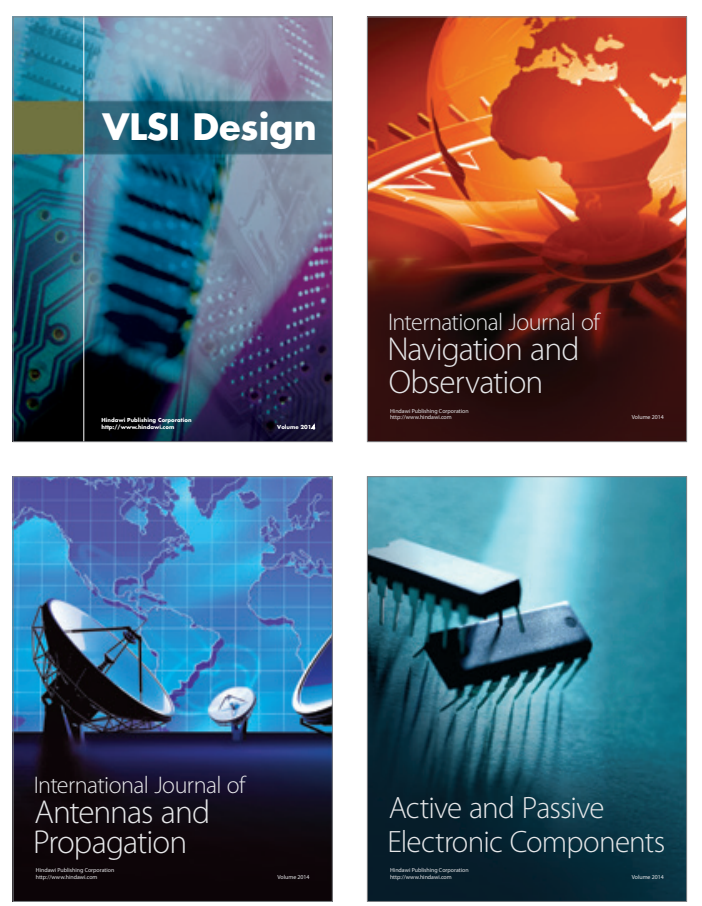
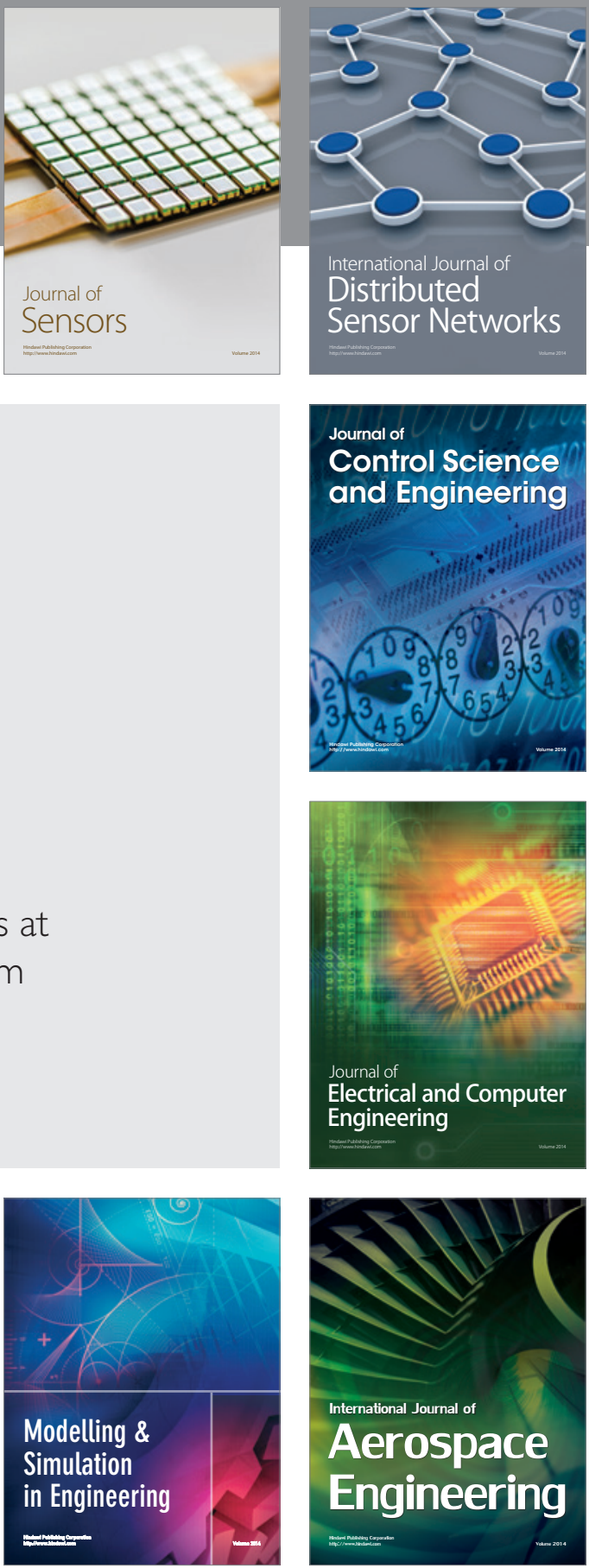

Journal of

Control Science

and Engineering
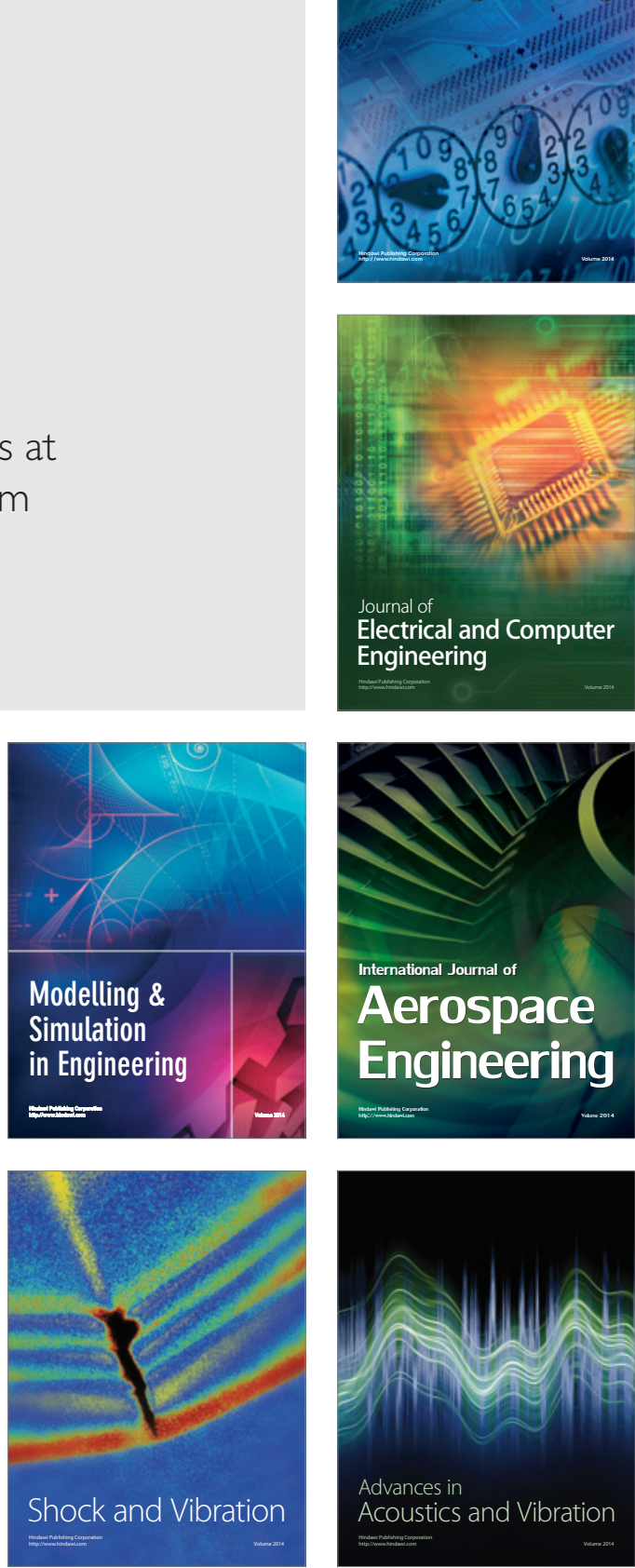